\title{
Pelatihan Pembuatan Peta Kelurahan Se-Kecamatan Galang Kota Batam
}

\author{
Sudra Irawan ${ }^{1}$, Oktavianto Gustin ${ }^{1}$, Arif Roziqin ${ }^{1}$, Rizki Widi Pratama ${ }^{1}$, Luthfiya Ratna Sari ${ }^{1}$, \\ Nanik Lestari ${ }^{2}$, Fajar Muliana ${ }^{1}$, Vina Selvia Dwiyanti ${ }^{1}$, Muslimin ${ }^{1}$, Gregorius Harry Saktian \\ Sinaga $^{1}$, Agus Fatulloh ${ }^{3}$, Miratul Khusna Mufida ${ }^{3}$, Afdhol Dzikri ${ }^{3}$, Evaliata Sembiring ${ }^{4}$, Selly \\ Artaty Zega ${ }^{5}$
}

\footnotetext{
${ }^{1}$ Program Studi Teknik Geomatika Jurusan Teknik Informatika Politeknik Negeri Batam, Jalan Ahmad Yani, Batam, Indonesia

${ }^{2}$ Program Studi Akuntansi Jurusan Managemen Bisnis Politeknik Negeri Batam, Jalan Ahmad Yani, Batam, Indonesia

${ }^{3}$ Program Studi Teknik Informatika Jurusan Teknik Informatika Politeknik Negeri Batam, Jalan Ahmad Yani, Batam, Indonesia

${ }^{4}$ Program Studi Multimedia dan Jaringan Jurusan Teknik Informatika Politeknik Negeri Batam, Jalan Ahmad Yani, Batam, Indonesia

${ }^{5}$ Program Studi Animasi Jurusan Teknik Informatika Politeknik Negeri Batam, Jalan Ahmad Yani, Batam, Indonesia
}

\begin{abstract}
Galang, with Sembulang as its capital city, is located in Batam, Riau Islands. Based on the results of the field survey on August $21^{\text {st }}$-23 ${ }^{\text {rd }} 2018$ conducted in the Galang Administration Office and the Sembulang Administration Office, it was found that there was no subdistrict and village map which is up to the cartographic rules, which could pose a problem. In fact, there were no villages in Galang, other than Sembulang, which possessed a village map. The awareness from the community regarding the importance of charting a village map was still relatively low, resulting in many errors regarding cartometric boundaries. In addition, the community and the village officials' understanding regarding the use of a map as a basis to manage space in developing the region was still also inadequate. To overcome this problem and fulfill the need of the people, the Galang Subdistrict Head approved this community service activity. The program aims to deliver a training on charting maps of villages in Sembulang, Batam, which consists of three main activities: instruction on the use of handheld GPS, delineation of Google Earth imagery, and documentation of geospatial information. The training (in the form of Bimtek) was carried out on Tuesday, August $6^{\text {th }}$, 2019, attended by 39 participants, comprising the Galang sub-district officials as well as the head, secretary, and officials of each village. The activities started from the delivery of topics regarding the scope of geospatial information and the use of map, followed by training in the use of handheld GPS to record spatial data such as public facilities and tourist attractions, and concluded by training in plotting village maps using the Argish software.
\end{abstract}

Keywords - Training, Village Map, Galang, geospatial information.

Abstrak - Kecamatan Galang, dengan Sembulang sebagai ibu Kota Kecamatan merupakan bagian dari Kota Batam, Provinsi Kepulauan Riau. Berdasarkan hasil survei lapangan yang dilaksanakan pada 21-23 Agustus 2018 di Kantor Kecamatan Galang dan Kantor Kelurahan Sembulang ditemukan beberapa masalah yaitu belum tersedianya peta kecamatan dan keluruhan atau desa yang sesuai dengan kaidah kartografis, bahkan hanya Desa Sembulang dari seluruh desa yang ada di Kecamatan Galang yang memiliki peta desa, desa yang lain belum punya. Keterlibatan masyarakat dalam pemetaan desa juga sangat kurang sehingga banyak terjadi kesalahpahaman dalam penentuan batas kartometrik. Selain itu, kurangnya pengetahuan masyarakat dan perangkat desa tentang penggunaan peta sebagai dasar pengelolaan ruang untuk mengembangkan potensi wilayah. Berdasarkan hal tersebut akan dilaksanakan kegiatan pengabdian sesuai dengan kebutuhan masyarakat (hasil diskusi dengan Camat Galang) yaitu pelatihan pembuatan peta desa dan kelurahan Se-Kecamatan Sembulang Kota Batam dengan 3 kegiatan utama yaitu, pertama pelatihan penggunaan GPS hanheld, deliniasi citra google earth, dan perekaman informasi geospasial. Kegiatan Pelatihan (Bimtek) Pembuatan Peta Desa dan Kelurahan Se-Kecamatan Galang, Kota Batam telah dilaksanakan pada Selasa, 6 Agustus 2019 dengan diikuti oleh 39 peserta. Peserta dalam kegiatan ini adalah perangkat Kecamatan Galang, Para Lurah, Sekretaris Lurah, dan perangkat kelurahan yang ada di Kecamatan Galang. Kegiatan pelatihan dimulai dengan 
penyampaian materi ruang lingkup informasi geospasial dan sosialisasi penggunaan peta, dilanjutkan dengan pelatihan penggunaan GPS Handheld untuk merekam data spasial seperti fasilitas umum dan lokasi wisata, dan pelatihan pembuatan peta desa dengan menggunakan software Argish.

Kata Kunci-Pelatihan, Peta Kelurahan, Galang, informasi geospasial.

\section{PEndahuluan}

Undang-undang Nomor 4 tahun 2011 tentang Informasi Geospasial menjelaskan bahwa Informasi Geospasial yang selanjutnya disingkat IG adalah data geospasial yang sudah diolah sehingga dapat digunakan sebagai alat bantu dalam perumusan kebijakan, pengambilan keputusan, dan/atau pelaksanaan kegiatan yang berhubungan dengan ruang kebumian, termasuk ditingkat kecamatan dan kelurahan. Pemahaman informasi geospasial berdasarkan pengamatan di lapangan dirasa kurang, terbukti dengan banyaknya masalah yang bersumber dari pemahaman ruang baik pemahaman ruang oleh pihak swasta, perorangan maupun masyarakat adat. Informasi kebumian terkait dengan pengelolaan ruang memerlukan peta untuk menunjukkan lokasi/posisi dan sebarannya. Peta merupakan gambaran permukaan bumi yang disajikan pada bidang datar menggunakan skala tertentu. Pada umumnya pembuatan peta dilakukan oleh instansi pemerintah tanpa melibatkan masyarakat sehingga terkadang informasi mengenai sumber daya alam dan potensi yang ada luput dari pemetaan. Banyak faktor yang menyebabkan keadaan tersebut terjadi seperti kurangnya pemahaman lokal mengenai suatu wilayah karena kurangnya informasi atau tidak dilibatkannya masyarakat setempat dalam proses pemetaan sehingga masyarakat perlu dilibatkan dalam proses pembuatan peta. Proses pemetaan dengan melibatkan masyarakat disebut dengan pemetaan partisipatif. Pemetaan partisipatif merupakan metode alternatif dalam penyediaan informasi spasial dimana masyarakat dapat berpartisipasi dalam proses pembuatan peta di desa mereka sendiri (Hapsari, dkk 2014). Masyarakat dapat membuat peta untuk kepentingan pengelolaan ruang, pembelajaran budaya lokal yang bermanfaat bagi keberlangsungan sumber daya alam serta untuk pengetahuan generasi selanjutnya. Tujuan dari pemetaan partisipatif adalah untuk meningkatkan kesadaran seluruh anggota masyarakat mengenai hak-hak mereka atas ruang dan sumber daya alam serta potensinya.

Kecamatan Galang, dengan Kota Sembulang dengan Ibu Kota Kecamatan yang merupakan bagian dari Kota Batam. Desa Sembulang belum memiliki peradaban yang maju, terlihat dari ketersediaan listrik yang belum 24 jam, ketersediaan air bersih dan akses signal telekomunikasi yang kurang baik. Padahal desa Sembulang memiliki potensi daerah yang bisa dikembangkan seperti pariwisata (pantai, resort dan area pemancingan) yang didukung dengan akses transportasi yang memadai baik darat (terminal Damri) maupun laut (pelabuhan lokal). Namun sampai saat ini, ketersediaan informasi spasial terkait hal-hal diatas belum ada. 


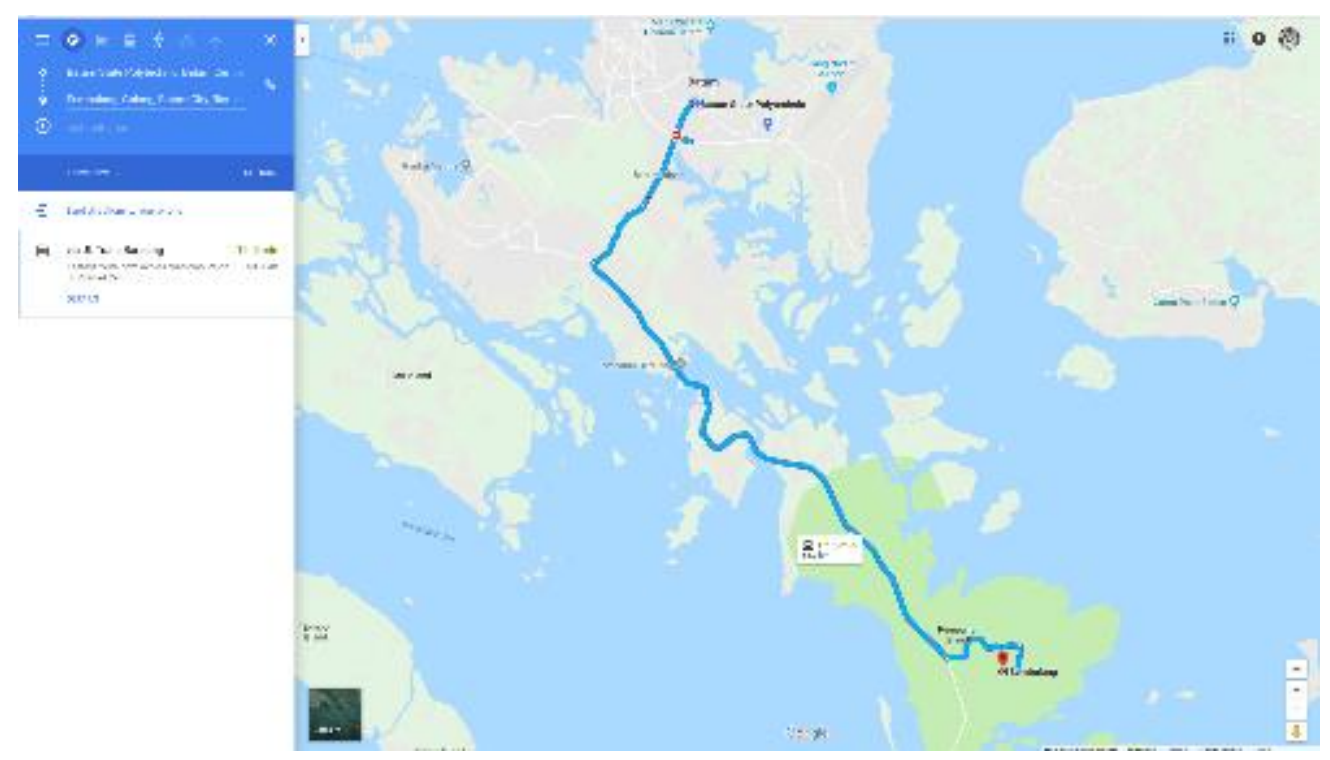

Gambar 1. Lokasi pengabdian masyarakat Desa Sembulang

Berdasarkan hasil survei lapangan yang dilaksanakan pada 21-23 Agustus 2018 di Kantor Kecamatan Galang dan Kantor Kelurahan Sembulang ditemukan beberapa masalah yaitu belum tersedianya peta kecamatan dan keluruhan atau desa yang sesuai dengan kaidah kartografis, bahkan untuk Desa Sembulang belum memiliki peta desa. Keterlibatan masyarakat dalam pemetaan desa juga sangat kurang sehingga banyak terjadi kesalahpahaman dalam penentuan batas kartometrik. Selain itu, kurangnya pengetahuan masyarakat dan perangkat desa tentang penggunaan peta sebagai dasar pengelolaan ruang untuk mengembangkan potensi wilayah.

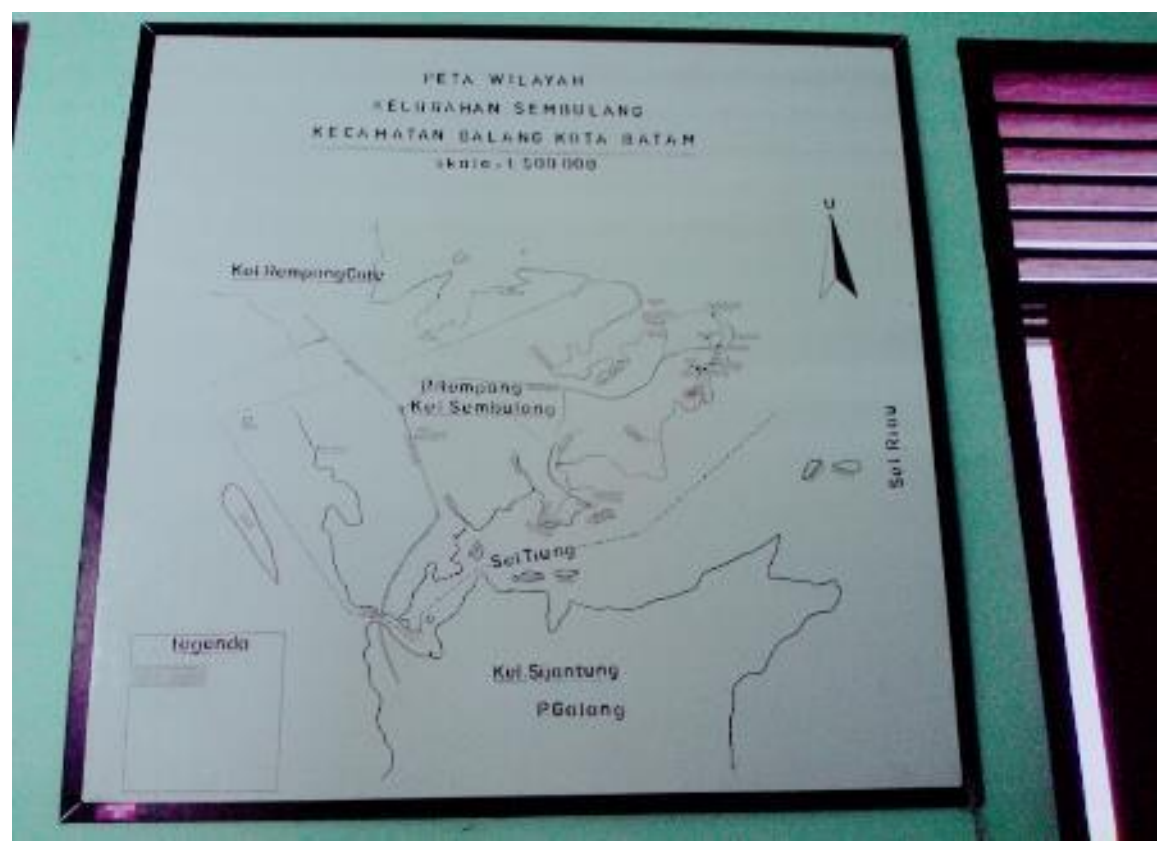

Gambar 2. Peta Desa Kelurahan Sembulang yang tidak sesuai dengan kaidah informasi dan minim informasi geospasial 
Gambar 2 merupakan satu sampel yang diambil peta desa yang terdapat di Kelurahan Sembulang, terlihat bahwa peta yang dibuat sudah 30 tahun yang lalu sehingga tidak mengambarkan kondisi kekinian dari desa tersebut, batas adminitrasi desa juga sudah berubah, termasuk batas desa, banyak informasi geospasial seperti jumlah rumah, fasilitas umum, rumah sakit, dan fasilitas lainnya yang tidak tercantum di peta dasa. Peta tersebut sangat minim informasi. Berdasarkan hal tersebut perlu dilakukan pelatihan pembuatan pembuatan peta desa dan leurahan bagi perangkat kecamatan, kelurahan, dan desa, serta masyarakat sehingga masyakarat memiliki pengetahuan dan keterampilan dalam membuat peta desa, yang berakibat semakin mudahnya dalam pengembangan dan pembangunan potensi dan keuangan desa kedepan

\section{TINJAUAN PUSTAKA}

Desa sebagai kesatuan masyarakat hukum yang memiliki batas-batas wilayah yang berwenang untuk mengatur dan mengurus kepentingan masyarakat setempat, berdasarkan asalusul dan adat istiadat setempat yang diakui dan dihormati eksistensinya dalam sistem Pemerintahan Negara Kesatuan Republik Indonesia (UU No.14 Tahun 2014). Perkembangan yang begitu cepat pada berbagai sektor pembangunan di desa sebagai akibat peningkatan intensitas kegiatan yang terkait dengan ruang menyebabkan ketidak seimbangan struktur dan fungsi ruang di pedesaan. Dinamika perkembangan desa yang terjadi, salah satunya adalah permasalahan batas wilayah desa (desa adat dan desa) sehingga dipandang perlu dilakukan pemetaan desa. Metode pemetaan desa mengacu pada Peraturan Kepala Badan Informasi Geospasial No. 3 tahun 2016 tentang Spesifikasi Teknis Penyajian Peta Desa. Keberhasilan dalam pemetaan desa akan mengacu pada asas keberpihakan, asas pemberdayaan dan asas percepatan. Survei dilaksanakan dengan menunjukan produk peta desa setempat (tersurvei) dan dilanjutkan dengan mengajukan pertanyaan kepada masyarakat guna mendapatkan masukan atas produk peta desa yang ada. Desa di NKRI mencapai sekitar 77.000 desa menjadikan pemetaan desa sebagai proyek besar yang harus segera diselesaikan, percepatan pemetaan desa dengan berbagai pilihan teknologi dan keterlibatan masyarakat (pemetaan partisipatif) akan sangat bermanfaat untuk memenuhi asas percepatan (Riadi, 2016).

Permasalahan di Indonesia hingga hari ini adalah bahwa batas administrasi kelurahan sudah ada, tetapi batas administrasi Rukun Warga/Rukun Tetangga (RW/RT) belum ada (Wibowo, \& Sudarmadji, 2010). Kenyataan di lapangan batas administrasi kelurahan tersebut masih belum disajikan dalam peta yang sesuai kaidah kartografis. Menurut Internasional Cartographic Assosiation (ICA) peta adalah suatu gambaran atau representasi unsur-unsur ketampakan abstrak yang dipilih dari permukaan bumi atau benda-benda angkasa (Virrantaus dkk, 2019). Berdasarkan isinya peta dibagi menjadi 2 yaitu peta umum dan tematik. Peta umum 
adalah peta yang memuat atau menggambarkan permukaan bumi yang berisi informasi secara umum dari suatu wilayah tertentu. Peta tematik adalah peta yang menggambarkan tema atau informasi tertentu dari permukaan bumi (Nurdin dan Madya, 2001).

Kemampuan aparat kelurahan dalam melakukan pendataan pemanfaatan ruang di perkotaan di kedua kelurahan mitra masih menggunakan basis data konvensional yang belum berbasis data digital. Untuk mengikuti perkembangan trend pelayanan publik yang mengarah pada integrasi basis data untuk kebutuhan multiuser, diperlukan pengembangan kapasitas Kelurahan dalam pemetaan wilayah melalui sistem informasi geografis. Hal ini juga untuk memastikan pendataan pemanfaatan ruang perkotaan yang dinamis dilakukan dengan bantuan satu sistem basis data yang dapat diperbaharui dengan efisien dan mudah digunakan (Putri, dkk, 2017).

Salah satu teknologi yang berkembang pesat yang bisa digunakan untuk memetakan informasi geospasial di permukaan bumi adalah teknologi penginderaan jauh. Putra (2017) memanfaatkan citra pengideraan jauh pada google earth untuk pembuatan peta citra di Kecamatan Marga, Kabupaten Tabanan. Kartanegara, dkk (2013) juga menggunakan citra penginderaan jauh untuk pembuatan peta kampus Universitas Diponegoro. Teknologi penginderaan jauh juga bermanfaat untuk menjaga kelestarian lingkungan. Irawan dan Malau (2016) melakukan analisis persebaran Mangrove di Pulau Batam menggunakan teknologi penginderaan jauh. Setahun berikutnya, Irawan dan Sirait (2017) menggunakan citra landsat 8 untuk menganalisis perubahan kerapatan vegetasi di kota Batam berbasis web.

Salah satu alat yang digunakan untuk merekam informasi geospasial termasuk data desa disebut Global Positioning System, disingkat GPS. GPS merupakan sistem satelit navigasi dan penentuan posisi yang dimiliki dan dikelola oleh Amerika Serikat. Sistem ini didesain untuk memberikan posisi dan kecepatan tiga-dimensi serta informasi mengenai waktu, secara kontinyu di seluruh dunia tanpa bergantung waktu dan cuaca, bagi banyak orang secara simultan. Saat ini GPS sudah banyak digunakan orang di seluruh dunia dalam berbagai bidang aplikasi yang menuntut informasi tentang posisi, kecepatan, percepatan ataupun waktu yang teliti. GPS dapat memberikan informasi posisi dengan ketelitian bervariasi dari beberapa millimeter (orde nol) sampai dengan puluhan meter. Prinsip penentuan posisi dengan GPS yaitu menggunakan metode reseksi jarak, dimana pengukuran jarak dilakukan secara simultan ke beberapa satelit yang telah diketahui koordinatnya. Pada pengukuran GPS, setiap epoknya memiliki empat parameter yang harus ditentukan : yaitu 3 parameter koordinat $\mathrm{X}, \mathrm{Y}, \mathrm{Z}$ atau L,B,h dan satu parameter kesalahan waktu akibat ketidaksinkronan jam osilator di satelit dengan jam di receiver GPS. Oleh karena diperlukan minimal pengukuran jarak ke empat satelit.

GPS selain digunakan pada aplikasi-aplikasi militer, bidang-bidang aplikasi GPS yang cukup marak saat ini antara lain meliputi survai pemetaan, geodinamika, geodesi, geologi, geofisik, 
transportasi dan navigasi, pemantauan deformasi, pertanian, kehutanan, dan bahkan juga bidang olahraga dan rekreasi. Di Indonesia sendiri penggunaan GPS sudah dimulai sejak beberapa tahun yang lalu dan terus berkembang sampai saat ini baik dalam volume maupun jenis aplikasinya. Zarodi, dkk (2019) memanfaatkan GPS Handheld untuk membuat peta batas dusun di Desa Sumber, Kecamatan Dukun, Kabupaten Magelang. Azizah dkk (2018) juga memanfaatkan GPS dan teknologi Unmanned Aerial Vehicle (UAV) untuk pemetaan desa di Desa Kepek, kecamatan Wonosari Kabupaten Gunung Kidul.

Dalam pembuatan peta menggunakan software tertentu seperti Argish atau Quantum GIS. Software ini merupakan bagian dari suatu sistem yang disebut Sistem Informasi Geografi (SIG). SIG merupakan sistem berbasis-komputer untuk pengambilan, penyimpanan, perolehan kembali, analisa, dan ruang atau referensi lokasi (Irwansyah, 2013). Teknologi SIG dapat digunakan dalam berbagai bidang, dapat digunakan untuk investifigasi ilmiah, pengelolaan sumberdaya, perencanaan pembangunan, kartografi, dan perencanaan rute. Handayani, dkk (2015) menggunakan Sistem Informasi Geografis untuk pemetaan jalan desa berbasis web. Irawan dan Zowtler (2017) juga memanfaatkan SIG berbasis Web untuk membuat aplikasi wisata di Kota Batam menggunakan layanan Location Based Service Berbasis. SIG juga dapat digunakan untuk memetakan harga jual tanah, sebagaimana yang dilakukan Astuti, dkk (2017) untuk memetakan harga tanah di Kecamatan Bengkong Kota Batam tahun 2017.

\section{METODE}

Pelatihan pembuatan peta desa/kelurahan ini dilaksanakan di Kecamatan Galang Kota Batam dengan pesertanya adalah seluruh Kepala Desa/Lurah, Perangkat Desa, serta ketua RT/RW se Kecamatan Galang. Metode pelaksanaan pengabdian masyarakat yang diajukan dibagi menjadi tiga tahapan yaitu pra lapangan, lapangan dan pasca lapangan. Tahap pra lapangan meliputi tahapan persiapan guna mengumpulkan alat dan bahan seperti GPS handheld, download citra Google Earth, materi pelatihan, dan persiapan lainnya. Tahap lapangan merupakan tahapan inti dalam program pengabdian masyarakat yaitu melakukan pelatihan penggunaan GPS pada masyarakat, deliniasi citra Google Earth, perekaman informasi geospasial dan pembuatan peta desa. Tahap akhir adalah tahap pasca lapangan yang meliputi evaluasi pelaksanaan program, penyajian hasil berupa peta desa dan pembuatan laporan (Gambar 3). 


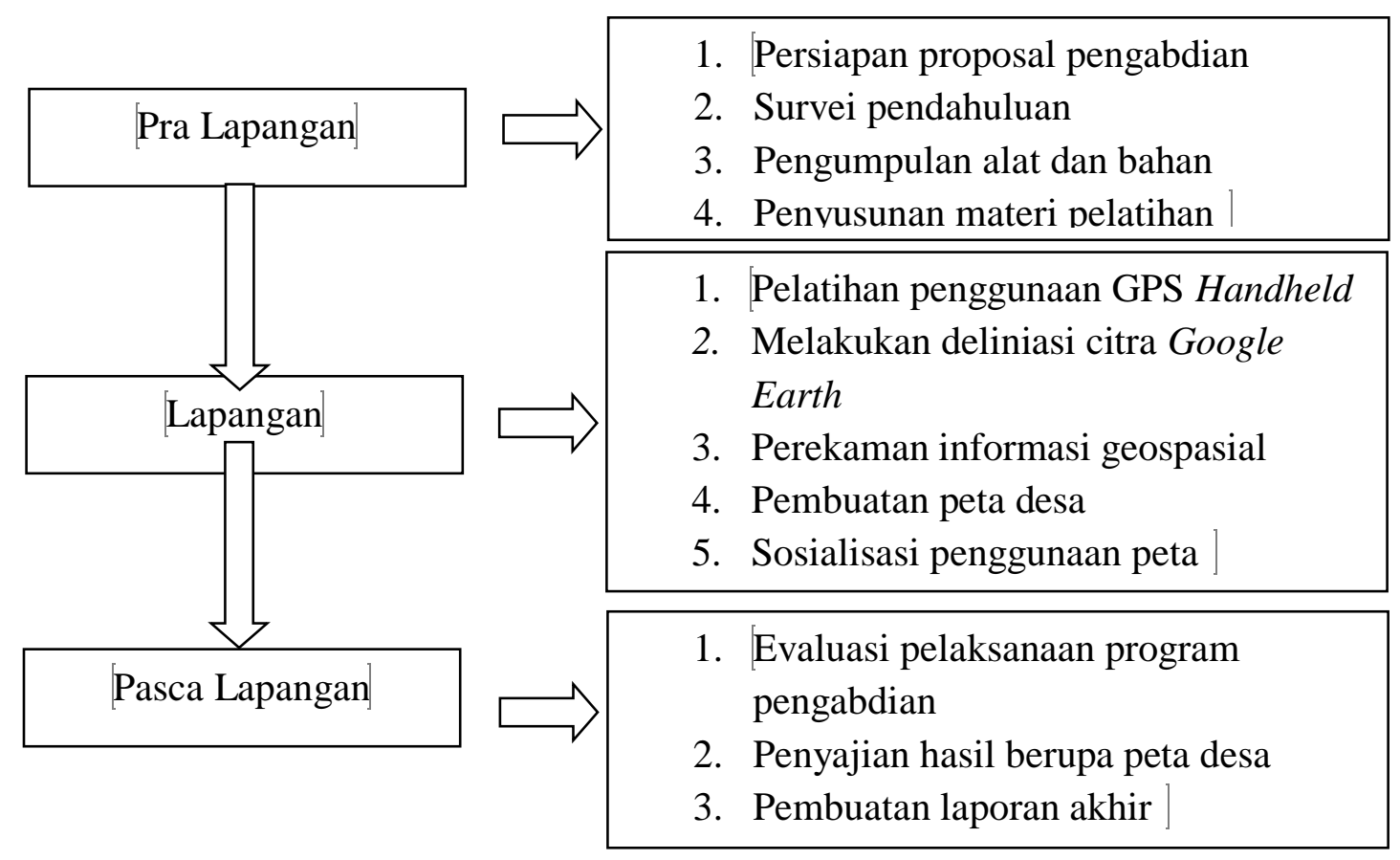

1

Gambar 3. Tahapan Pengabdian Masyarakat

Dalam pelaksanaan program pengabdian ini, masyarakat diajak berpartisipasi langsung melalui pelatihan dan pemetaan desa dengan didampingi oleh mahasiswa/pengabdi. Kegiatan pelatihan kepada perangkat desa dilaksanakan 5 kali dengan urutan materi yang terstruktur sehingga hasil dari pelatihan ini masing-masing perangkat desa menghasilkan satu peta desa yang diusulkan ke Kecamatan untuk diterbitkan menjadi peta desa.

Mitra sangat berperan dalam pelaksanaan kegiatan, terutama dalam penyediaan peserta dan tempat pelaksanaan kegiatan. Berdasarkan hasil wawancara dan diskusi dengan pihak kecamatan galang bahwa untuk penyediaan transportasi dan penyediaan tempat dengan segala fasilitasnya pihak kecamatan yang akan menanggungnya.

Evaluasi pelaksanaan program dan keberlanjutan program di lapangan setelah kegiatan pengabdian akan terus dilakukan terutama terkait update data fasilitas umum dan batas desa yang mungkin berubah. Oleh karena itu monitoring dan komunikasi antara pengabdi dan mitra akan terus dilakukan baik via WA ataupun email. Pengabdi juga harus memastikan peta desa harus sudah terpasang di ruang rapat atau pertemuan setelah kegiatan lapangan pengabdian dilaksanakan karena tidak memungkinkan peta desa selesai dalam beberapa hari. Butuh waktu yang cukup panjang, bisa dua sampai tiga bulan setelah kegiatan. Jadi pemantauan dan bimbingan harus tetap dilaksanakan. 


\section{IV.HASIL DAN PEMBAHASAN}

Kegiatan Pelatihan (Bimtek) Pembuatan Peta Desa dan Kelurahan Se-Kecamatan Galang, Kota Batam telah dilaksanakan pada Selasa, 6 Agustus 2019 dari pukul 8 pagi sampai 5 sore dengan diikuti oleh 39 peserta. Peserta dalam kegiatan ini adalah perangkat Kecamatan Galang, Para Lurah, Sekretaris Lurah, dan perangkat kelurahan yang ada di Kecamatan Galang.

Ketua pengabdian masyarakat ini sekaligus merupakan Kepala Program Studi Teknik Geomatika, Sudra Irawan, dalam sambutannya pada acara ini mengatakan bahwa asal ide kegiatan ini dari pengamatan di lapangan ditemukan banyaknya Kecamatan dan kelurahan yang belum memiliki peta kecamatan dan kelurahan, kalaupun ada petanya belum sesuai dengan kaidah kartografis. Ini tidak hanya terjadi di Kecamatan dan kelurahan di Galang, namun juga terjadi pada wilayah lainnya di Indonesia. Politeknik Negeri Batam sebagai pusat pengembangan dan penerapan ilmu pengetahuan dan teknologi ingin memberikan pengetahuan dan keterampilan dasar tentang cara membuat peta terutama peta desa dengan baik dan benar, ujarnya.

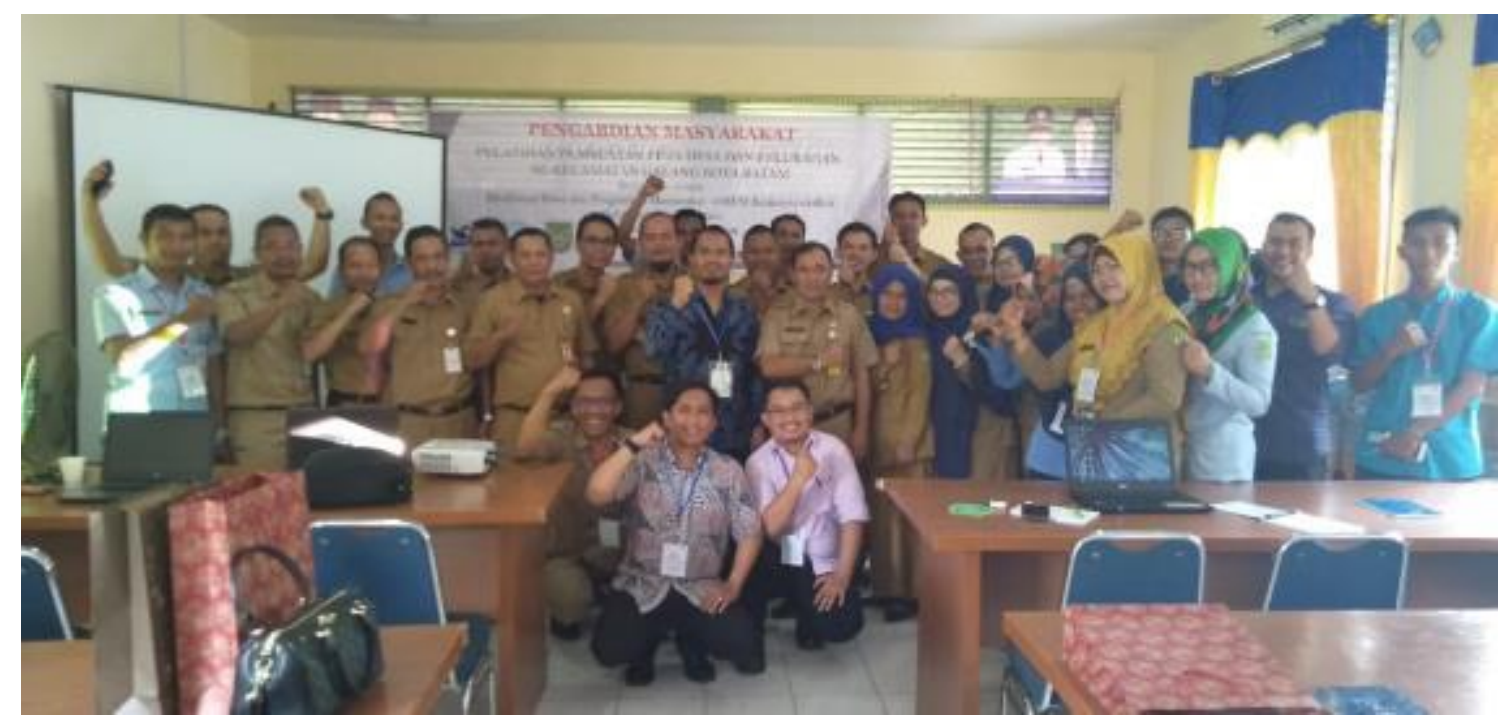

Gambar 4. Foto bersama setelah selesai pembukaan acara.

Ute Rambe, S.E, Sekretaris Kecamatan, mewakili Camat Galang dalam sambutannya dan sekaligus membuka acara mengucapkan terima kasih dan mengapresiasi Politeknik Negeri Batam yang peduli dan bersedia memberikan ilmunya melalui kegiatan ini kepada pejabat kecamatan dan kelurahan beserta jajarannya. Beliau juga berharap setelah pelatihan ini Para Lurah beserta jajarannya mampu membuat peta kelurahan sehingga ini dapat bermanfaat dalam pengembangan kelurahan kedepan.

Peserta pelatihan sangat antusias mengikuti kegiatan ini, salah satunya Irdawati, peserta pelatihan asal Kelurahan Air Raja, rela jauh-jauh datang dengan menempuh perjalalanan laut 
sekitar 5 jam demi mendapatkan ilmu. Kegiatan pelatihan dimulai dengan penyampaian materi ruang lingkup informasi geospasial dan sosialisasi penggunaan peta oleh Sudra Irawan, dilanjutkan dengan pelatihan penggunaan GPS Handheld oleh Oktavianto Gustin untuk merekam data spasial seperti fasilitas umum dan lokasi wisata, dan pelatihan pembuatan peta desa dengan menggunakan software Argish yang disampaikan Arif Roziqin.

Kegiatan ini juga melibatkan mahasiswa Prodi Teknik Geomatika Politeknik Negeri Batam untuk membimbing secara teknis di lapangan saat menggunakan GPS Handheld dan saat menggunakan software Argish. Mahasiswa tersebut adalah Fajar Muliana, Muslimin, Vina Selvia Dwiyanti, dan Gregorius Harry Saktian Sinaga.
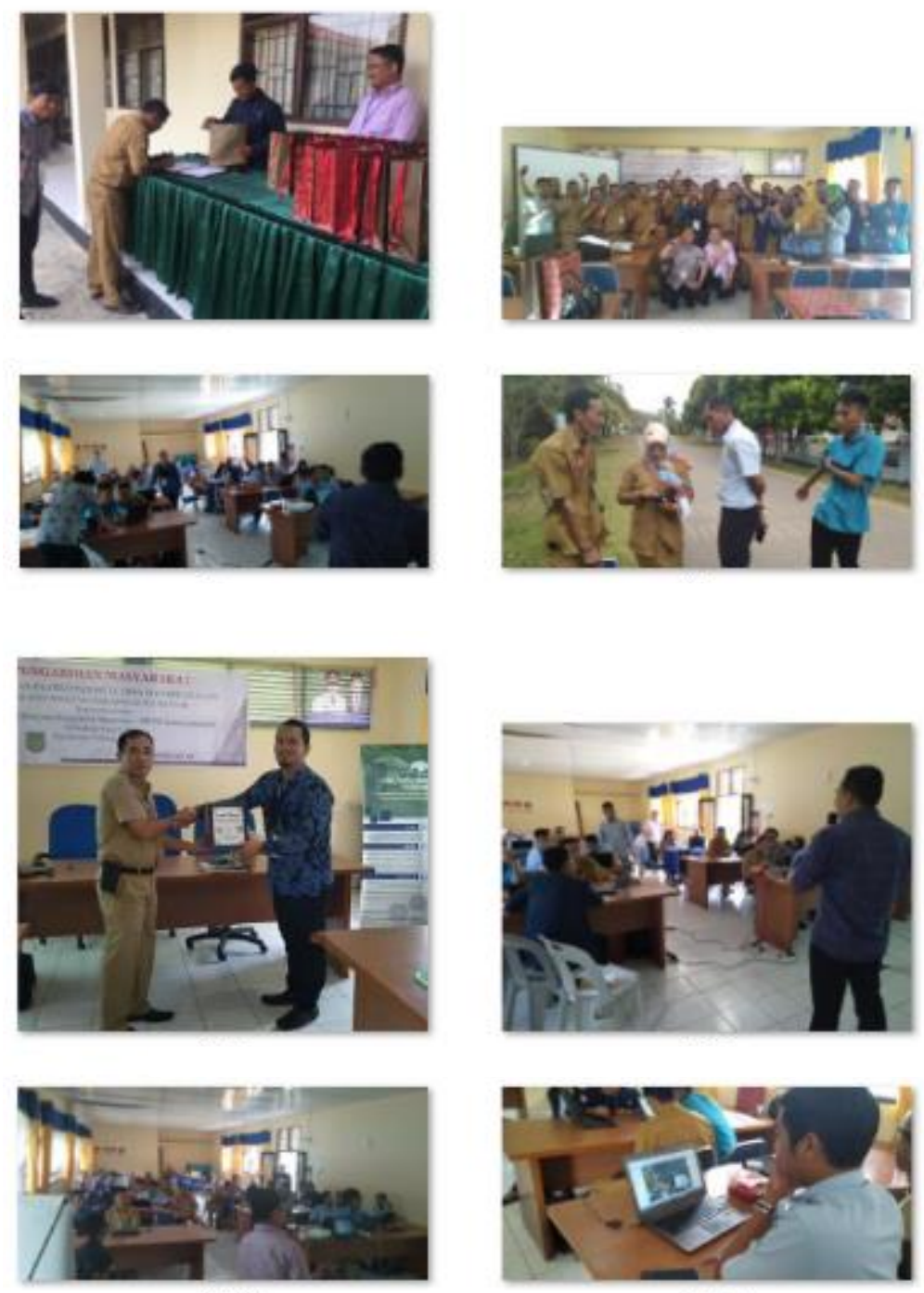

Gambar 5. Pelaksanaan Kegiatan
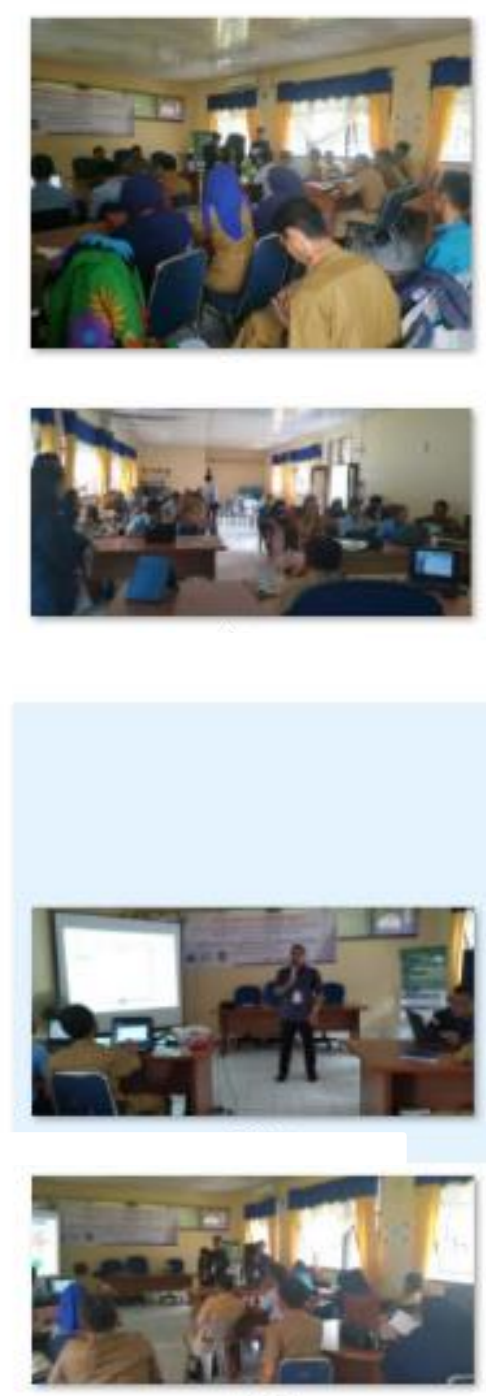


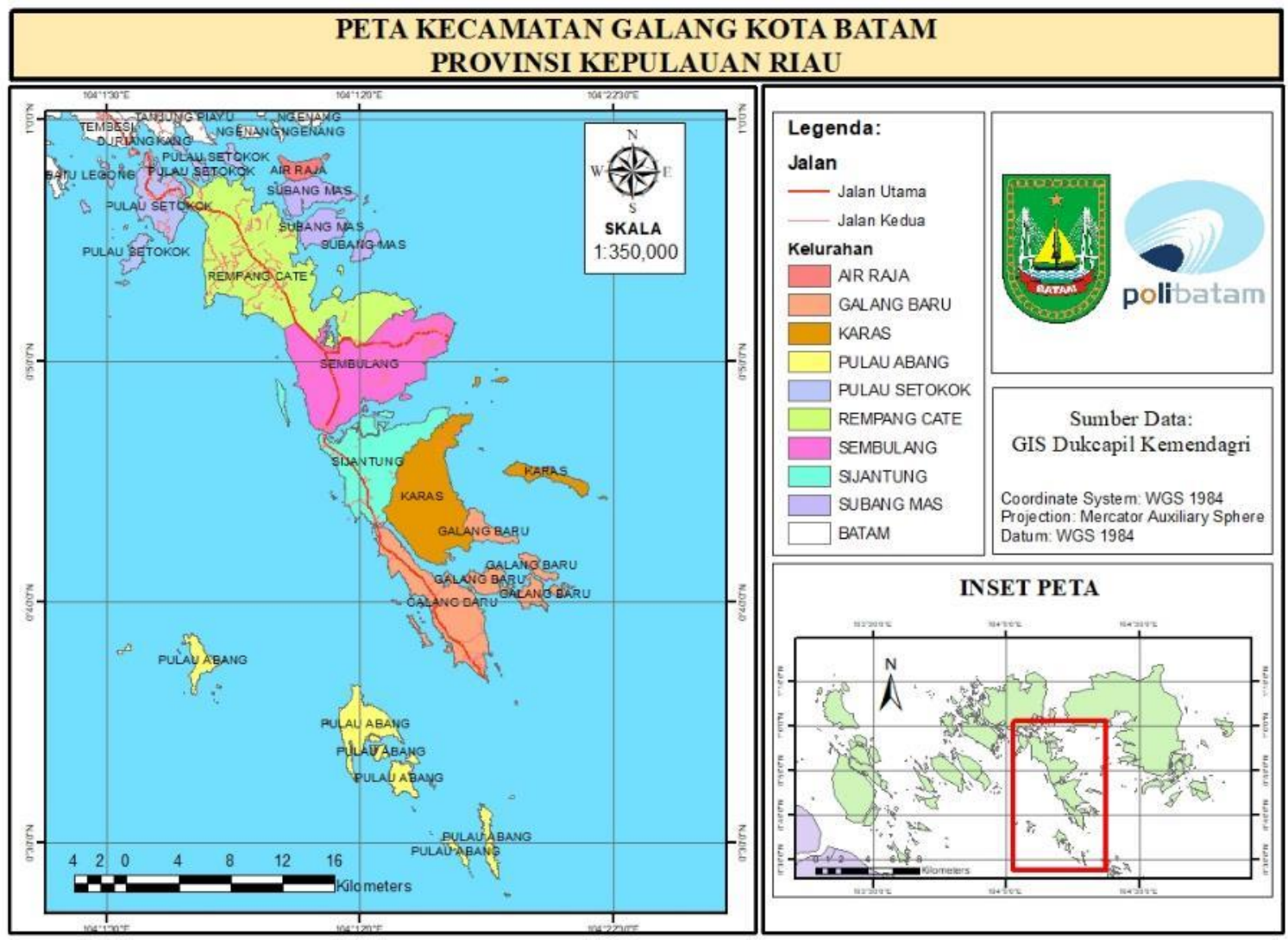

Gambar 6. Produk peta yang dihasilkan perangkat Kecamatan Galang

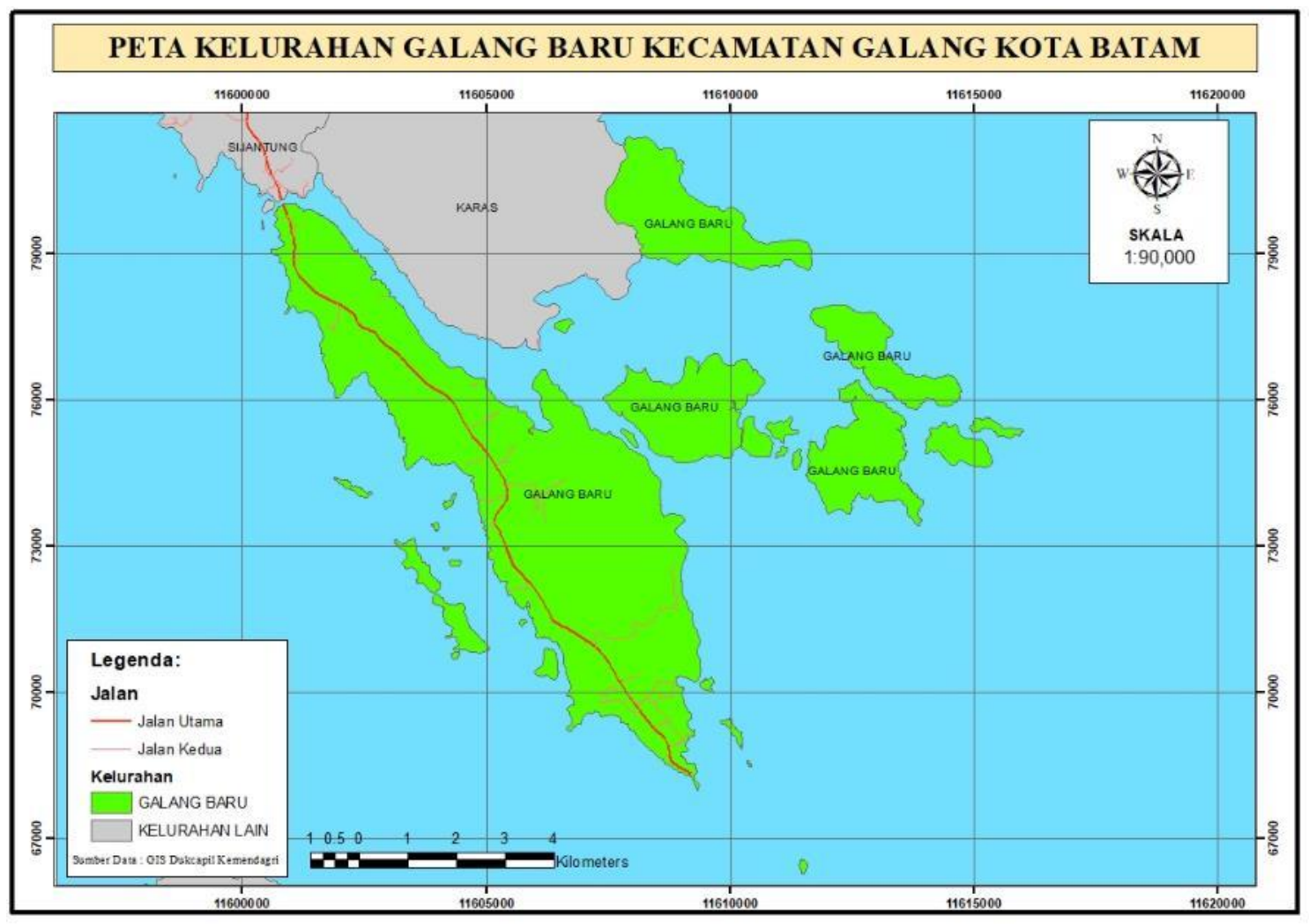

Gambar 7. Produk peta yang dihasilkan perangkat Kelurahan Galang Baru. 


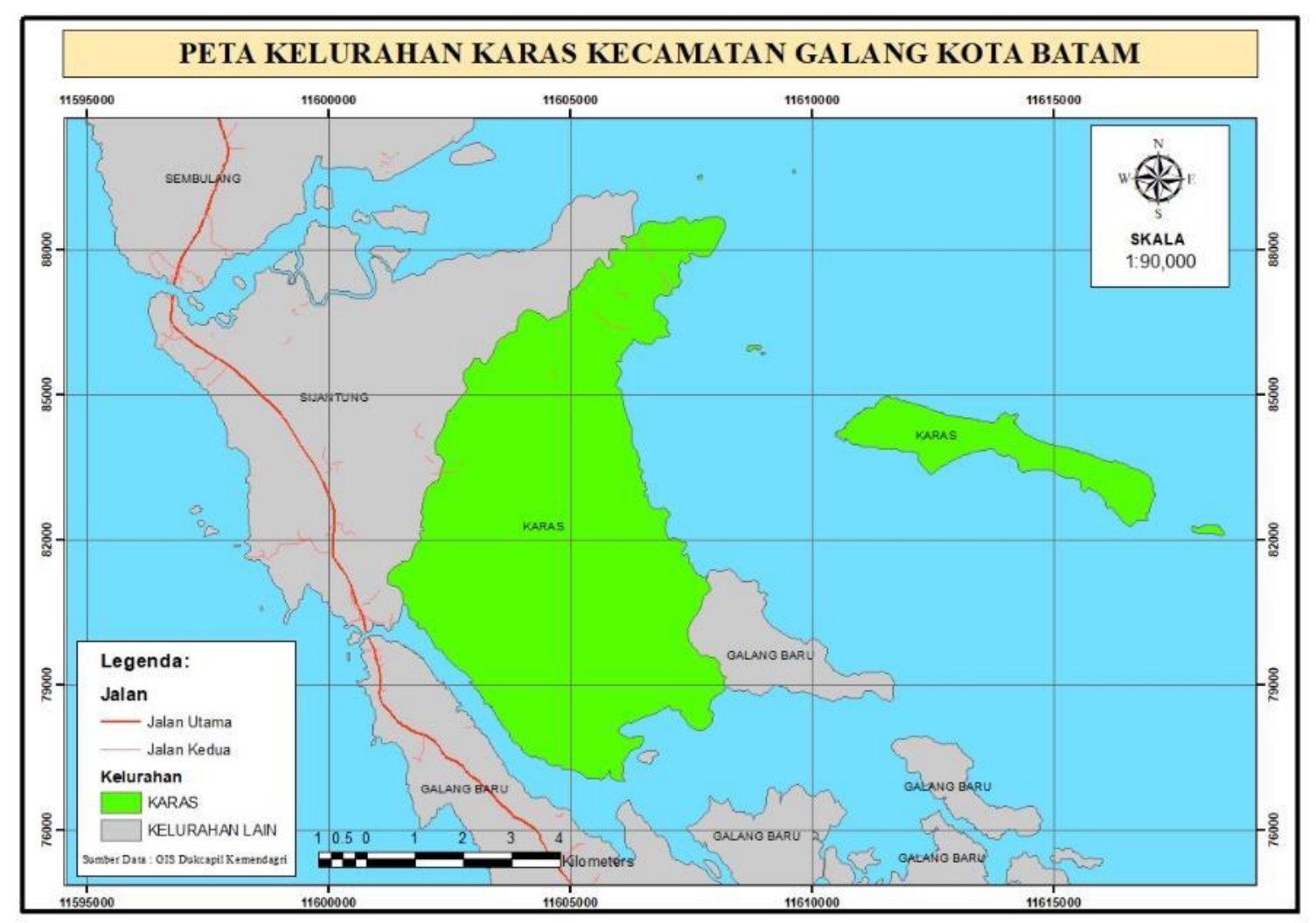

Gambar 8. Produk peta yang dihasilkan perangkat Kelurahan Karas.

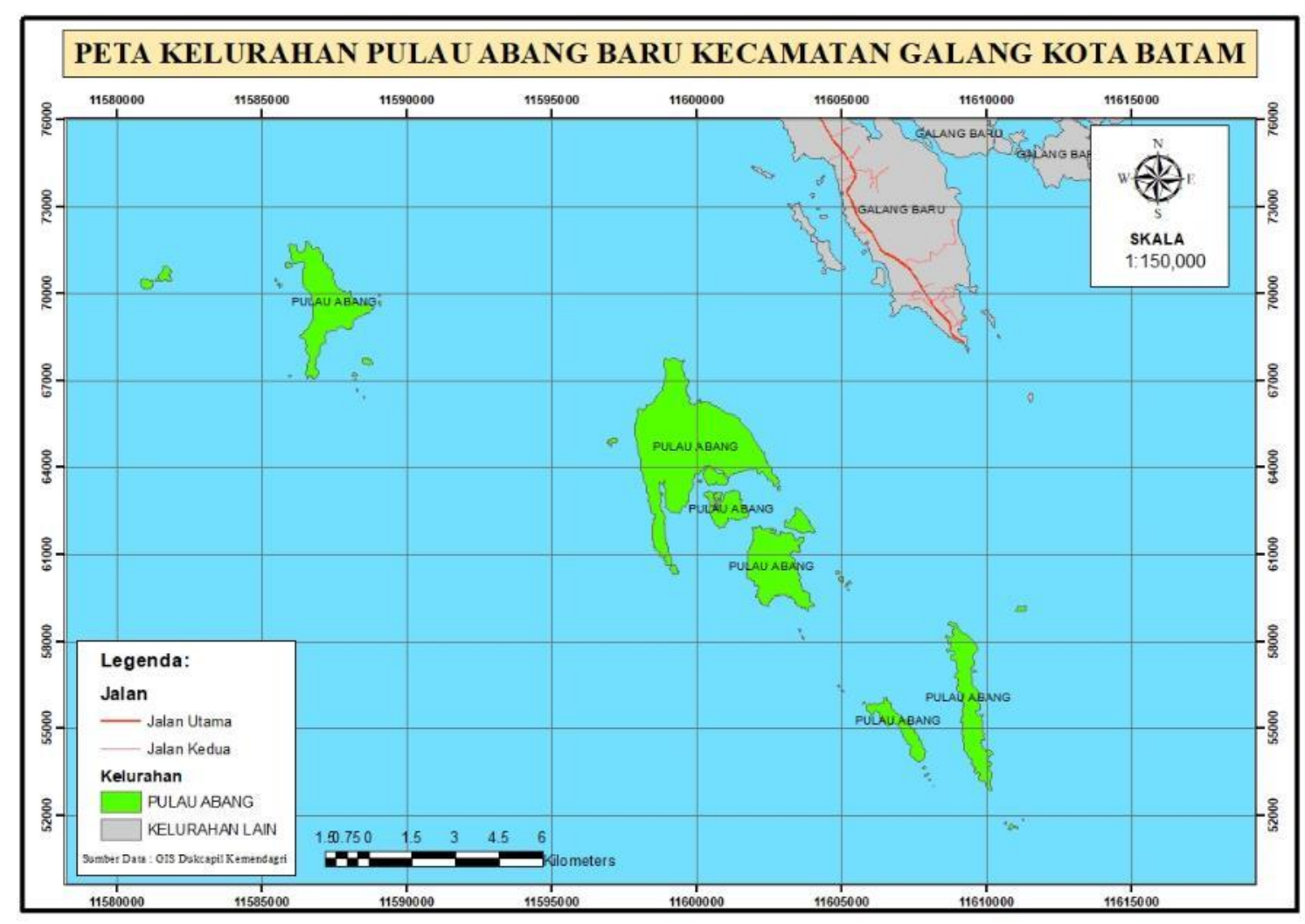

Gambar 9. Produk peta yang dihasilkan perangkat Kelurahan Pulau Abang 


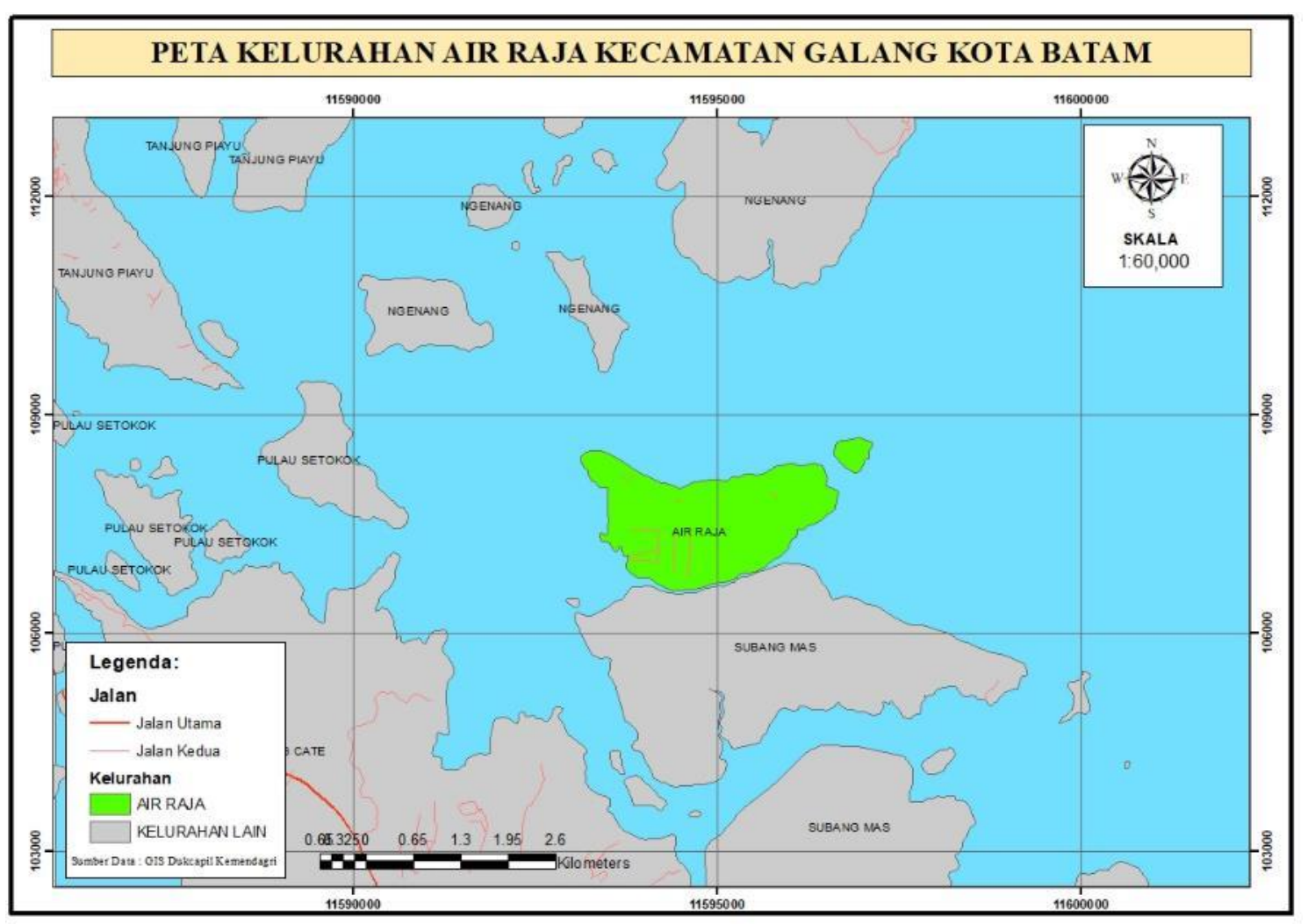

Gambar 10. Produk peta yang dihasilkan perangkat Kelurahan Air Raja

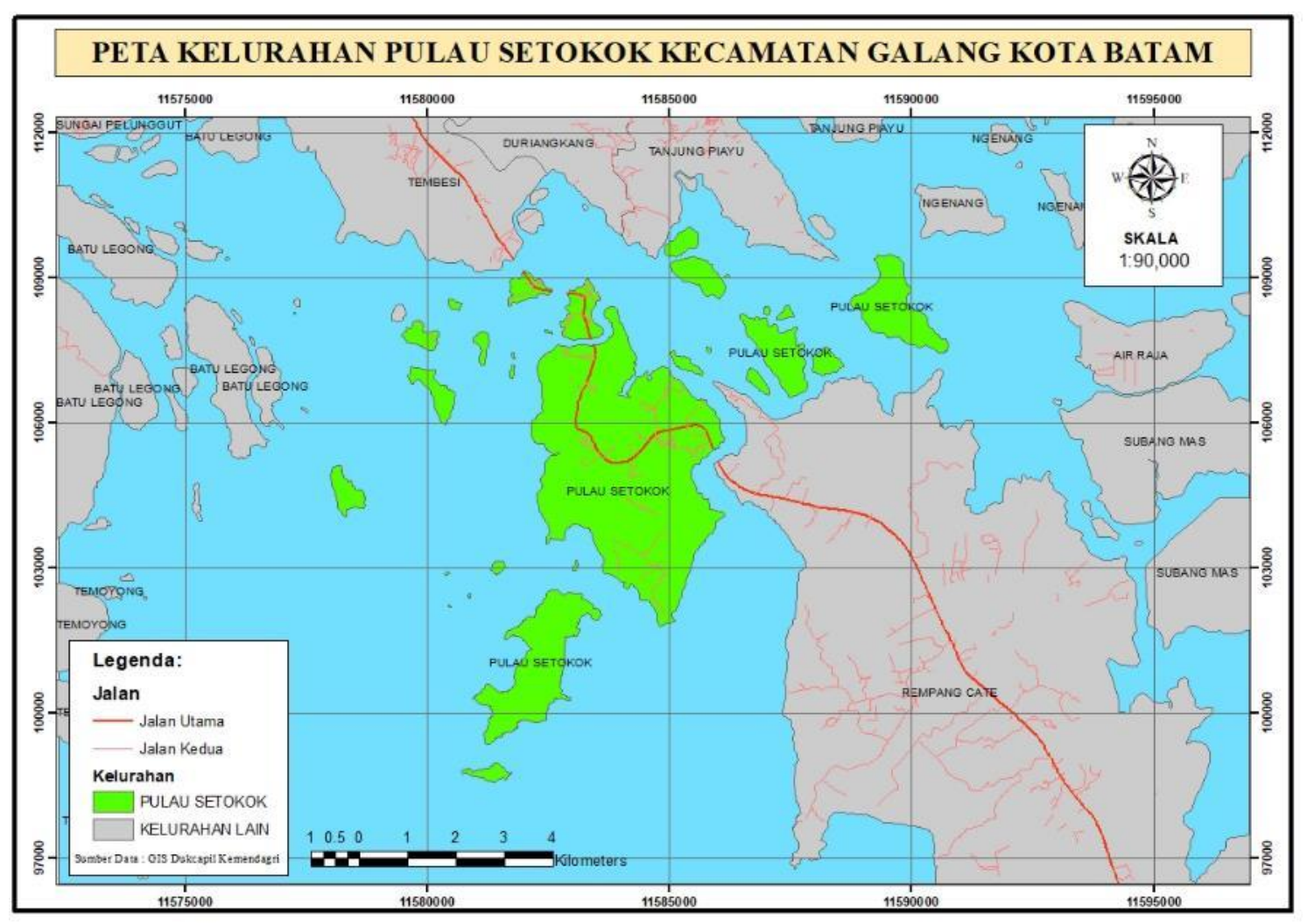

Gambar 11. Produk peta yang dihasilkan perangkat Kelurahan Pulau Setokok 


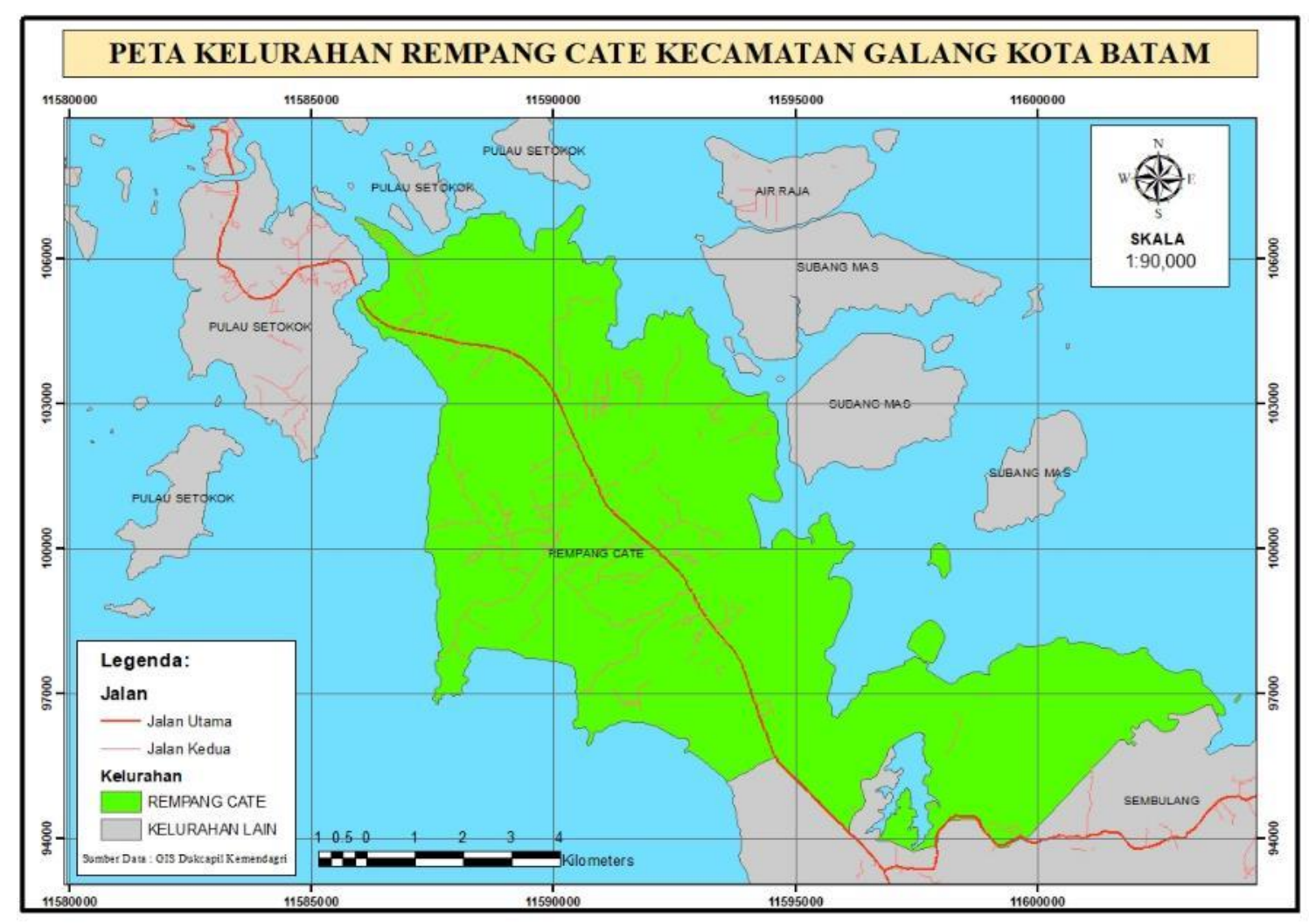

Gambar 12. Produk peta yang dihasilkan perangkat Kelurahan Rempang Cate

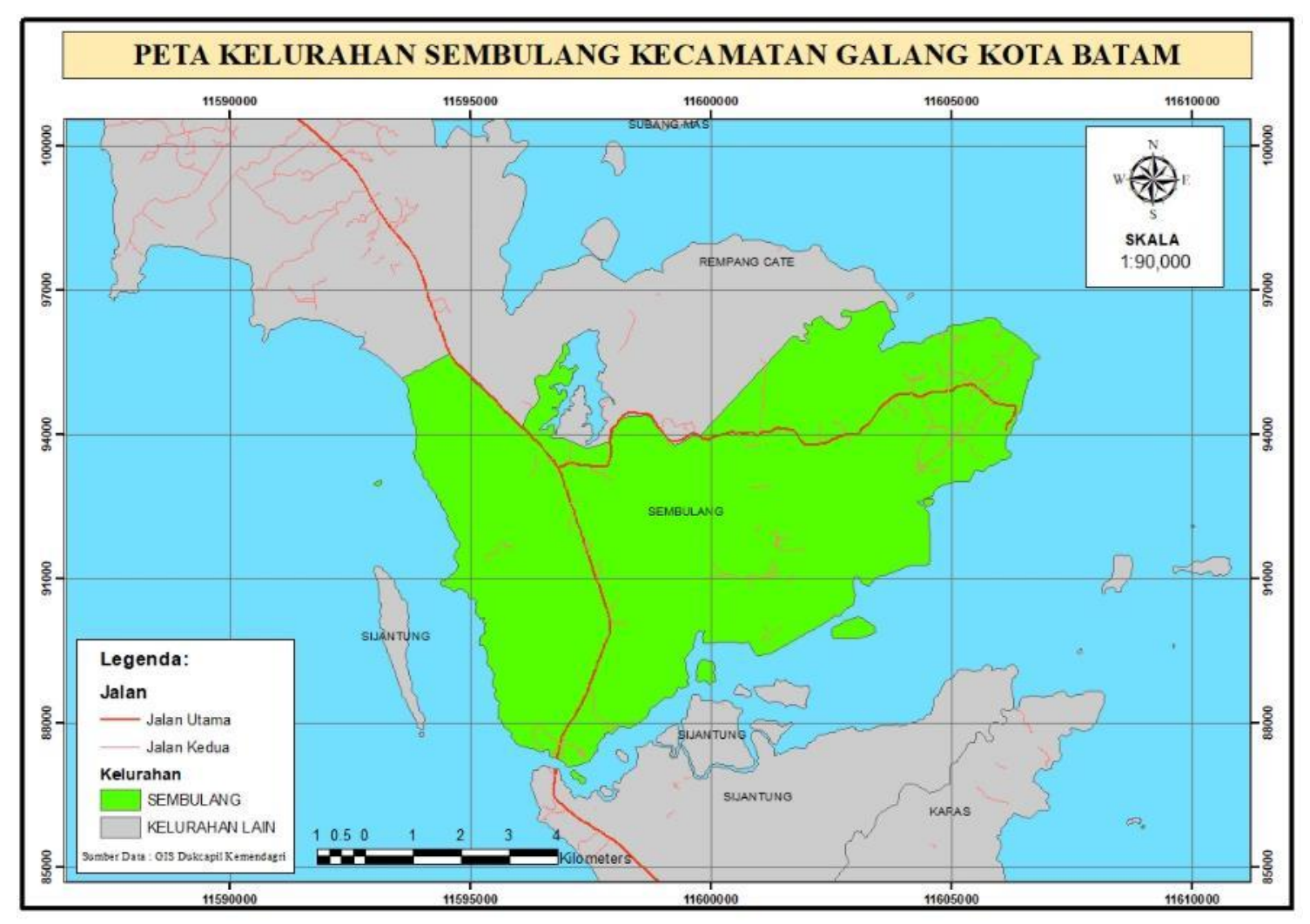

Gambar 13. Produk peta yang dihasilkan perangkat Kelurahan Sembulang 


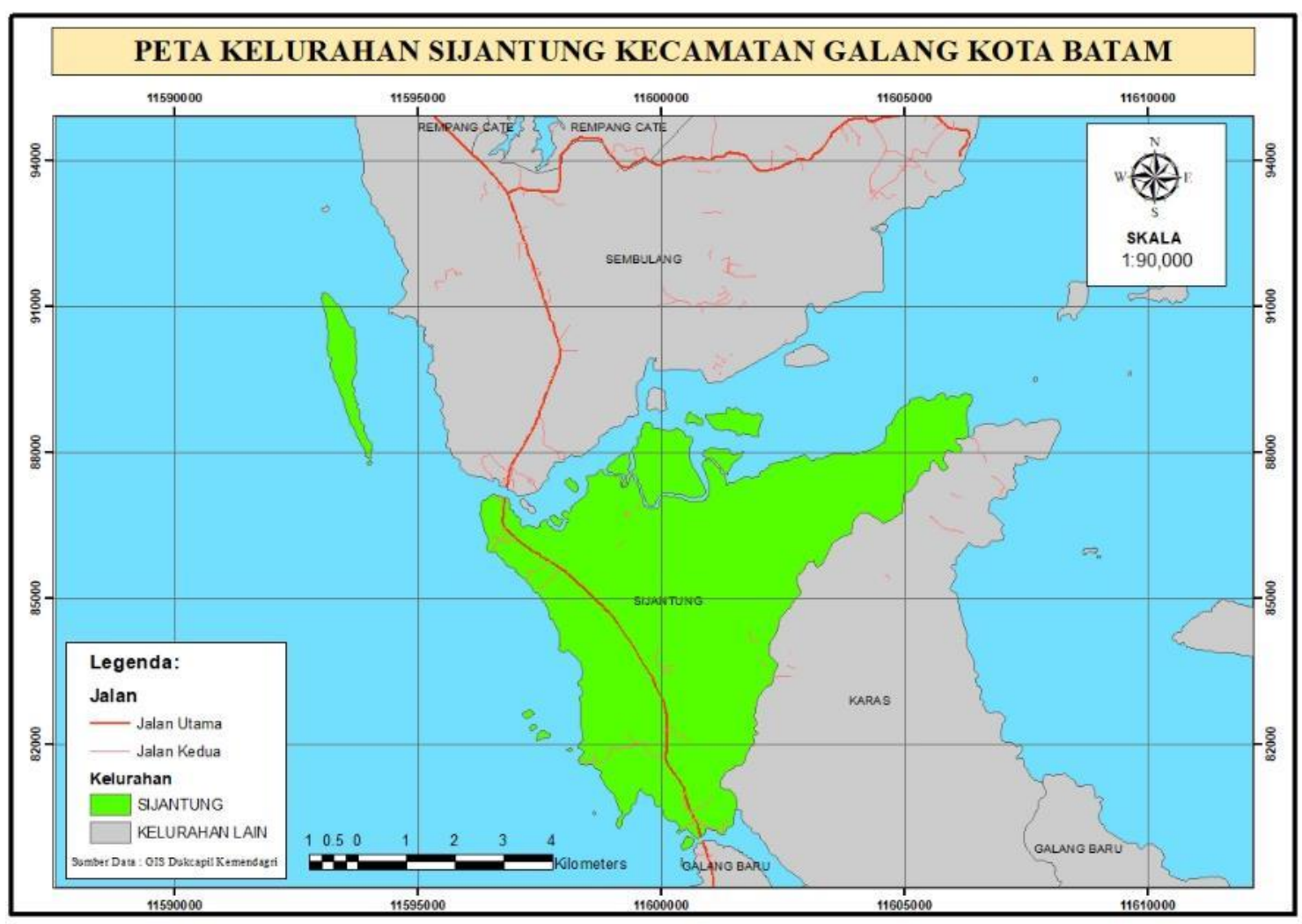

Gambar 14. Produk peta yang dihasilkan perangkat Kelurahan Sijantung

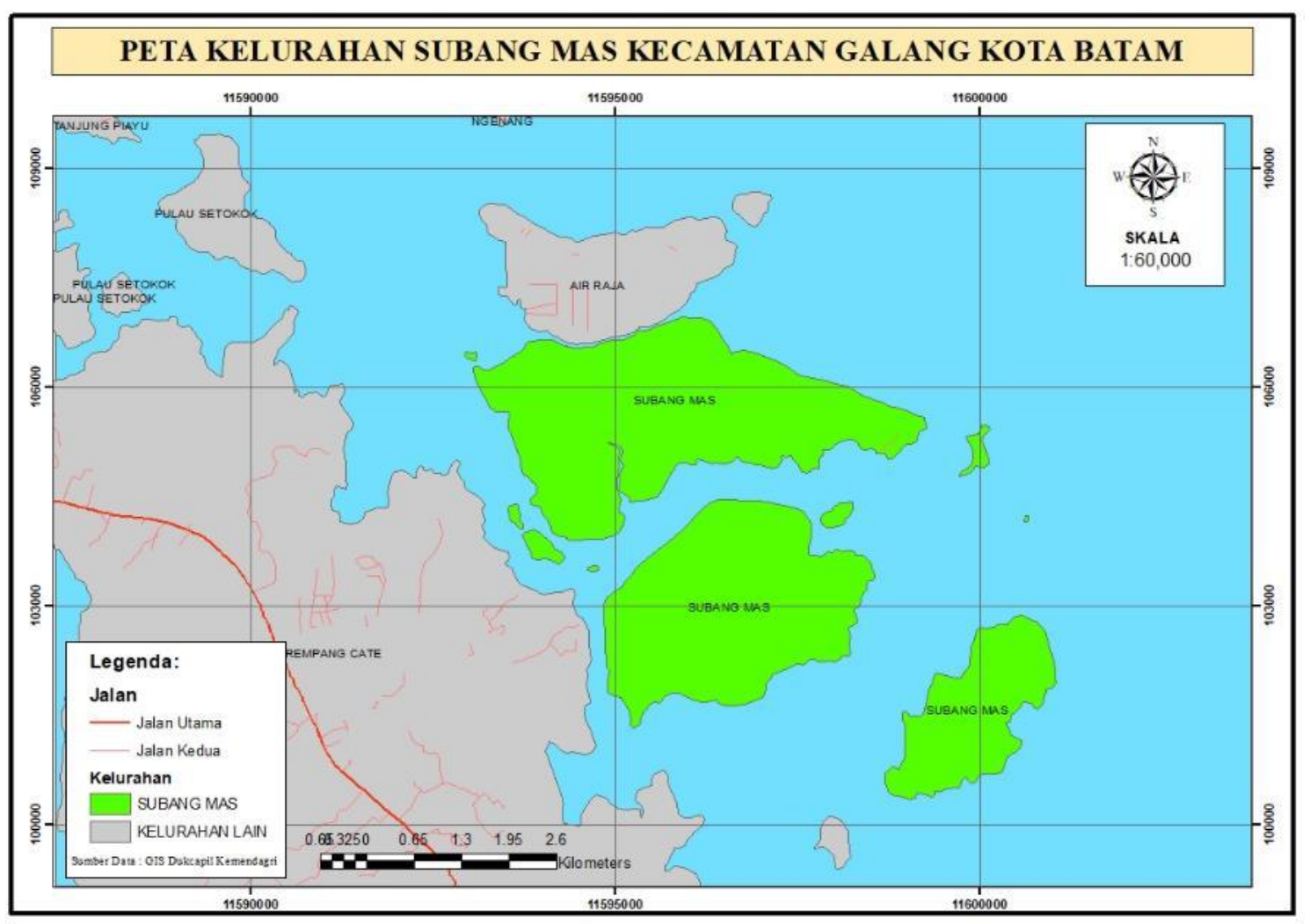

Gambar 15. Produk peta yang dihasilkan perangkat Kelurahan Subang Mas 
Kegiatan pengabdian yang dilakukan mampu memberikan pengetahuan dan keterampilan bagi Perangkat kecamatan dan kelurahan tentang pentingnya peta kelurahan dalam pengembangan desa. Pada pengabdian ini juga, peserta diberikan pemahaman potensi Provinsi Kepulauan Riau yang berbatasan dengan negara singapura, malaysia, vietnam, kamboja, serta memiliki sumberdaya alam yang melimpah mulai dari batuan dan logam, potensi laut dan perikanan, pariwisata, perkapalan, dan industri logistik. Peserta juga diberikan pemahaman tentang pekerjaan di bidang Survei Terestris, Sistem Informasi Geografis (SIG), dan Survei Hidrografi. Pada bidang survei terestris pemanfaatannya dapat digunakan untuk pengukuran luas tanah, pengukuran beda tinggi, perencanaan bangunan, menentukan titik kontrol, menentukan topografi lahan, dan lain-lain. Pekerjaan di bidang SIG misalnya memanfaatkan SIG untuk lingkungan misalnya pemantauan pencemaran, kerusakan lingkungan, termasuk pemantauan suhu global. Pada bidang perencanaan SIG digunakan untuk perencanaan pemukiman, perencanaan kota, perencanaan lokasi industri, perencanaan galian untuk fasilitas umum. Pada bidang marketing SIG dapat digunakan untuk pementukan lokasi bank, swalayan, mall, mesin ATM, hotel, rumah sakit. Pada bidang pariwisata SIG digunakan untuk inventarisasi daerah pariwisata dan analisis potensi unggulan. Pada bidang transportasi dapat digunakan untuk inventarisasi jaringan jalan, analisis daerah rawan kecelakaan, penentuan jalur darurat. Peserta juga diberikan pemahaman tentang pekerjaan yang dapat dilakukan di bidang hidrogarfi, seperti pengukuran kedalaman laut, pengindntifikasian jenis-jenis lapisan sedimen dasar laut, pemetaan bawah laut, pencarian kapal-kapal karan di dasar laut, penentuan jalur pipa dan kabel dasar laut, analisis dampak lingkungan di dasar laut.

Pada pelatihan GPS hanheld peserta diberikan pemahaman tentang pengertian GPS dan kegunaannya, tombol-tombol dan fungsi dari alat GPS handheld, menghidupkan dan mematikan GPS Handheld, merekam informasi geospasial dan menyimpannya dalam GPS handheld. Pada kegiatan pembuatan peta dengan menggunakan Software Argish peserta diberikan pemahaman tentang data raster yang diperoleh dari teknologi penginderaan jauh, cara melakukan download peta. Selanjutnya peserta diajarkan melakukan digitasi peta sesuai dengan kelurahan masingmasing, termasuk membagi RT dan RW, kemudian memasukan data geospasial yang diperoleh dengan menggunakan GPS Handheld ke dalam database SIG. Setelah selesai baru dilaksanakan layout peta sesuai dengan kaidah kartografis.

Berdasarkan analisis kuesioner evaluasi pengabdian, bahwa melalui pelatihan ini, setiap peserta memahami cara penggunaan GPS Handheld dan terampil menggunakannya untuk mereka data geospasial. Peserta pelatihan juga mampu menguasai software Argish, hal ini dibuktikan dengan produk peta yang dihasilkan. Jadi, secara keseluruhan peserta pelatihan telah menguasai 
kompetensi membuat peta kelurahan sehingga mampu menjawab permasalahan kedepan dalam rangka pengembangan Kelurahan.

Pada kuesioner evaluasi pelatihan, jumlah butir aspek yang dievaluasi terdiri dari 9 butir dengan skor jawaban 1 sampai 4. Hal ini berarti skor ideal tertinggi adalah 36 dan skor terendah adalah 9. Dengan demikian, mean ideal $(\mathrm{Mi})=1 / 2(36+9)=22,5$ dan standar deviasi ideal (SDi) $=1 / 6(36+9)=7,5$. Berdasarkan nilai ini maka batasan-batasan kategori penilaian untuk dievaluasi dapat disusun pada Tabel 1 berikut.

Tabel 1. Kriteria Evaluasi Pelaksanaan Program Pengabdian

\begin{tabular}{|c|c|}
\hline Rentang Skor & Kategori \\
\hline$X>33,75$ & Sangat baik \\
\hline $26,25<X \leq 33,75$ & Baik \\
\hline $18,75<X \leq 26,25$ & Cukup \\
\hline $11,25<X \leq 18,75$ & Kurang \\
\hline$X \leq 11,25$ & Sangat Kurang \\
\hline
\end{tabular}

Teknik yang digunakan untuk menentukan kategori penilaian masing-masing aspek yang mendukung evaluasi program pengabdian didasarkan pada Tabel 1 yang selanjutnya disesuaikan dengan rentang skor ideal masing-masing aspek tersebut.

Hasil analisis kuesioner diperoleh nilai 34,5 atau sekitar 95,83\% yang berdarkan Tabel 1 termasuk kategori sangat baik, artinya program pengabdian ini telah berhasil yang ditandai dengan 4 hal yaitu, materi pelatihan mampu dipahami oleh seluruh peserta, narasumber/instruktur mampu memberikan materi dengan jelas, runut, dan mudah dipahami peserta, fasilitas pelatihan yang diberikan memadai, serta kebermanfaatan yang diperoleh dari pengabdian ini yaitu setiap peserta mampu menggunakan GPS handheld dan membuat peta kelurahan masing-masing.

Kedepan, kegiatan pelatihan ini dikembangkan kembali terutama berkaitan dengan fasilitas penunjang pelatihan seperti komputer karena tidak semua peserta membawa komputer sehingga harus bergantian. Kedepan, harapannya pelatihan dilaksanakan di Laboratorium komputer atau setiap peserta membawa komputer.

Program pengabdian ini tidak akan berhenti sampai bulan Desember saja, tetapi akan dilakukan tindaklanjut sebagai berikut:

a. Monitoring ke perangkat kelurahan untuk menambahkan data koordinat dan data atribut meliputi kantor kelurahan, fasilitas umum, tempat wisata, pemukiman penduduk sehingga peta ini dapat dijadikan sebagai dasar dalam pengambilan kebijakan dan pengembangan kelurahan kedepan.

b. Berencana tahun 2020 melakukan pengabdian lanjutan yaitu Pelatihan Pembuatan Website Desa Berbasis Geographic Information System untuk Pengembangan Pariwisata di 
Kecamatan Galang Kota Batam. Peta desa yang dihasilkan akan ditampilkan dalam website sehingga bisa diakses oleh semua orang.

\section{KESIMPULAN}

Kegiatan Pelatihan pembuatan peta desa dan kelurahan Se-Kecamatan Galang, Kota Batam telah dilaksanakan dengan diikuti oleh 39 peserta yang merupakan perangkat Kecamatan Galang, Para Lurah, Sekretaris Lurah, dan perangkat kelurahan yang ada di Kecamatan Galang. Kegiatan pelatihan dimulai dengan penyampaian materi ruang lingkup informasi geospasial dan sosialisasi penggunaan peta, dilanjutkan dengan pelatihan penggunaan GPS Handheld untuk merekam data spasial seperti fasilitas umum dan lokasi wisata, dan pelatihan pembuatan peta desa dengan menggunakan software Argish. Setiap peserta pelatihan telah menguasai kompetensi membuat peta kelurahan sehingga mampu menjawab permasalahan kedepan dalam rangka pengembangan Kelurahan.

\section{UCAPAN TERIMA KASIH}

Penulis mengucapkan terima kasih kepada Direktorat Riset dan Pengabdian Masyarakat (DRPM) Kementerian Riset, Teknologi, dan Pendidikan Tinggi atas didanainya kegiatan pengabdian ini melalui Skema Hibah Program Kemitraan Masyarakat (PKM). Penulis juga berterima kasih kepada rekan dosen yang bersedia menjadi pemateri, serta memberikan saran, solusi, dan kritikan membangun agar pengabdian ini berjalan dengan lancar. Serta kepada Camat Galang yang telah bersedia dan membantu kami dalam pelaksanaan kegiatan pengabdian ini

\section{DAFTAR PUSTAKA}

Astutik, V., Irawan, S., \& Anurogo, W. (2017). Geographic Information System For The Mapping Of Value Land Zone Of District Bengkong Based On AHP Analysis. Journal of Applied Geospatial Information, 1(2), 49-57.

Handayani, L. G. S., Piarsa, I. N., \& Wibawa, K. S. (2015). Sistem Informasi Geografis Pemetaan Jalan Desa Berbasis Web. Lontar Komputer: Jurnal Ilmiah Teknologi Informasi, 128137.

Irawan, S., \& Malau, A. O. (2016). Analisis Persebaran Mangrove di Pulau Batam Menggunakan Teknologi Penginderaan Jauh. Jurnal Integrasi, 8(2), 80-87.

Irawan, S., \& Sirait, J. (2017). Perubahan kerapatan vegetasi menggunakan citra landsat 8 di kota Batam berbasis web. Jurnal Kelautan: Indonesian Journal of Marine Science and Technology, 10(2), 174-184.

Irwansyah, E. (2013). Sistem informasi geografis: prinsip dasar dan pengembangan aplikasi. DigiBook Yogyakarta.

Kertanegara, U., Nugraha, A. L., \& Sudarsono, B. (2013). Peninjauan Secara Kartografis Dalam Pembuatan Peta Kampus Universitas Diponegoro. Jurnal Geodesi Undip, 2(4). 
Nurdin, Y., \& Madya, W. (2001). Peta, Atlas, dan Globe Makanan Pokok IPS Geografi.

Putra, I. W. K. E. (2017). Pemanfaatan Citra Pengideraan Jauh Pada Google Earth Untuk Pembuatan Peta Citra Di Kecamatan Marga, Kabupaten Tabanan. Media Komunikasi Geografi, 18(1).

Putri, R. A., Rini, E. F., Rahayu, M. J., \& Andini, I. (2017). Kapasitas Sumber Daya Kelurahan dalam Meningkatkan Pelayanan Publik Berbasis Informasi Geospasial. Region: Jurnal Pembangunan Wilayah dan Perencanaan Partisipatif, 12(2), 206-211.

Riadi, B. (2016). Kajian Produk Peta Desa Badan Informasi Geospasial. In Seminar Nasional Geomatika (pp. 127-137).

Virrantaus, K., Fairbairn, D., \& Kraak, M. J. (2009). ICA research agenda on cartography and GI science. The Cartographic Journal, 46(2), 63-75.

Wibowo, A., \& Sudarmadji, B. W. (2010). Peta Skala Besar (Batas Rw) Dan Manfaatnya. Majalah Ilmiah Globe, 12(1).

Zarodi, H., Rofi, A., Anshori, M., \& Widarto, M. (2019). Pemanfaatan Teknologi GIS \& Penginderaan Jauh untuk Membuat Peta Batas Dusun Partisipatif di Desa Sumber, Kecamatan Dukun, Kabupaten Magelang. Seminar Nasional GEOTIK 2019. 